\title{
Strain driven fast osseointegration of implants
} Ulrich Joos ${ }^{\dagger}$, Andre Büchter ${ }^{\dagger}$, Hans-Peter Wiesmann ${ }^{\dagger}$ and Ulrich Meyer*

Address: Department of Cranio-Maxillofacial Surgery, University of Münster, Waldeyerstraße 30, D-48129 Münster, Germany

Email: Ulrich Joos - Joos@uni-muenster.de; Andre Büchter - buchtea@uni-muenster.de; Hans-Peter Wiesmann - wiesmap@uni-muenster.de; Ulrich Meyer* - ulmeyer@uni-muenster.de

* Corresponding author †Equal contributors

Published: 0I September 2005

Head \& Face Medicine 2005, I:6 doi:I0.1 186/I746-160X-I-6

This article is available from: http://www.head-face-med.com/content/I/I/6

(C) 2005 Joos et al; licensee BioMed Central Ltd.

This is an Open Access article distributed under the terms of the Creative Commons Attribution License (http://creativecommons.org/licenses/by/2.0), which permits unrestricted use, distribution, and reproduction in any medium, provided the original work is properly cited.
Received: 03 May 2005

Accepted: 0I September 2005

\begin{abstract}
Background: Although the bone's capability of dental implant osseointegration has clinically been utilised as early as in the Gallo-Roman population, the specific mechanisms for the emergence and maintenance of peri-implant bone under functional load have not been identified. Here we show that under immediate loading of specially designed dental implants with masticatory loads, osseointegration is rapidly achieved.
\end{abstract}

Methods: We examined the bone reaction around non- and immediately loaded dental implants inserted in the mandible of mature minipigs during the presently assumed time for osseointegration. We used threaded conical titanium implants containing a titanium2+ oxide surface, allowing direct bone contact after insertion. The external geometry was designed according to finite element analysis: the calculation showed that physiological amplitudes of strain (500-3,000 ustrain) generated through mastication were homogenously distributed in peri-implant bone. The strain-energy density (SED) rate under assessment of a I Hz loading cycle was $150 \mathrm{Jm}$ $3 \mathrm{~s}-\mathrm{I}$, peak dislocations were lower then $\mathrm{nm}$.

Results: Bone was in direct contact to the implant surface (bone/implant contact rate $90 \%$ ) from day one of implant insertion, as quantified by undecalcified histological sections. This effect was substantiated by ultrastructural analysis of intimate osteoblast attachment and mature collagen mineralisation at the titanium surface. We detected no loss in the intimate bone/implant bond during the experimental period of either control or experimental animals, indicating that immediate load had no adverse effect on bone structure in peri-implant bone.

Conclusion: In terms of clinical relevance, the load related bone reaction at the implant interface may in combination with substrate effects be responsible for an immediate osseointegration state.

\section{Findings}

Although the bone's capability of dental implant osseointegration has clinically been utilised as early as in the Gallo-Roman population [1], the specific mechanisms for the emergence and maintenance of peri-implant bone under functional load have not been identified. Here we show that under immediate loading of specially designed dental implants with masticatory loads, osseointegration is rapidly achieved. As the osseointegration state is much faster reached than commonly assumed, osseointegration is a strain dependant highly dynamic process.

Osseointegration is defined as a direct and stable anchorage of an implant by the formation of bony tissue without 


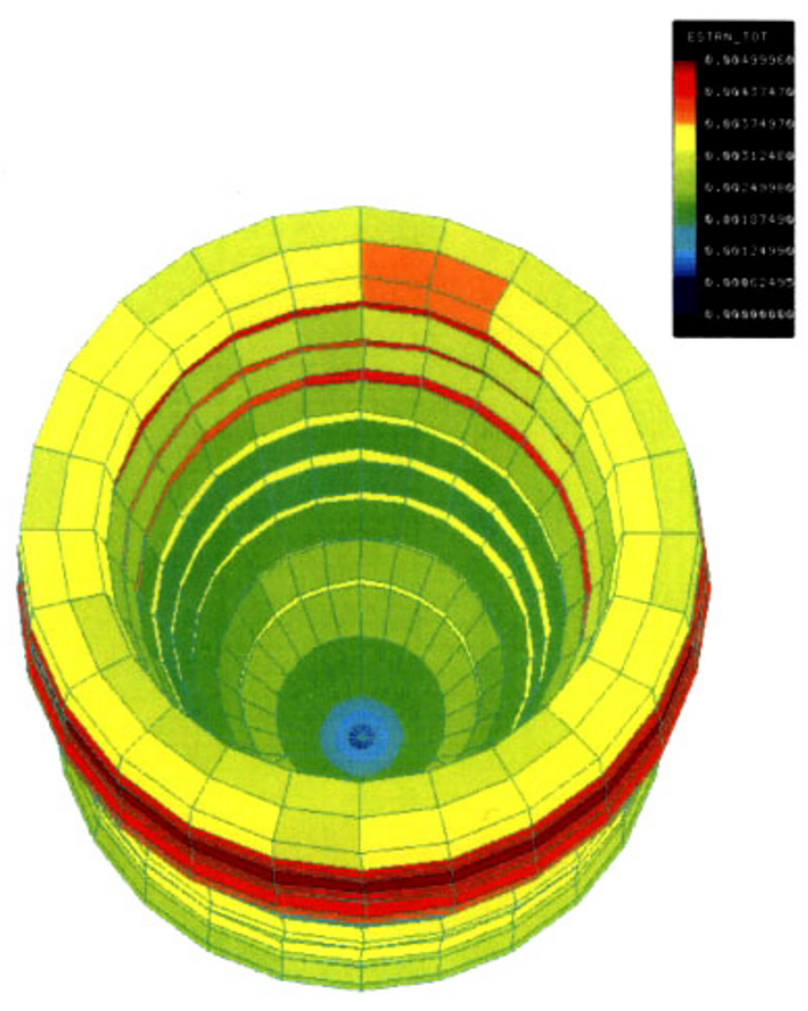

Figure I

Biomechanics and biology of implant osseointegration.

growth of fibrous tissue at the bone-implant interface [2]. A defining feature of osseointegration is that osteoblasts and mineralized matrix contacts the implant surface even when loads are applied. A common perception is that several weeks must be given to achieve implant osseointegration.

We have departed from this time related hypothesis by proposing that only minimal time (for example few hours, the time that is necessary for osteoblast adhesion on artificial substrates [3]) is required for osseointegration when the peri-implant tissue receives an optimal mechanical environment. We examined the bone reaction around non- and immediately loaded dental implants inserted in the mandible of mature minipigs during the presently assumed time for osseointegration (approved by the Animal Ethics Committee of the University of Münster under the reference number G 90/99). We used threaded conical titanium implants containing a titanium ${ }^{2+}$ oxide surface, allowing direct bone contact after insertion. The external geometry was designed according to finite element analy-

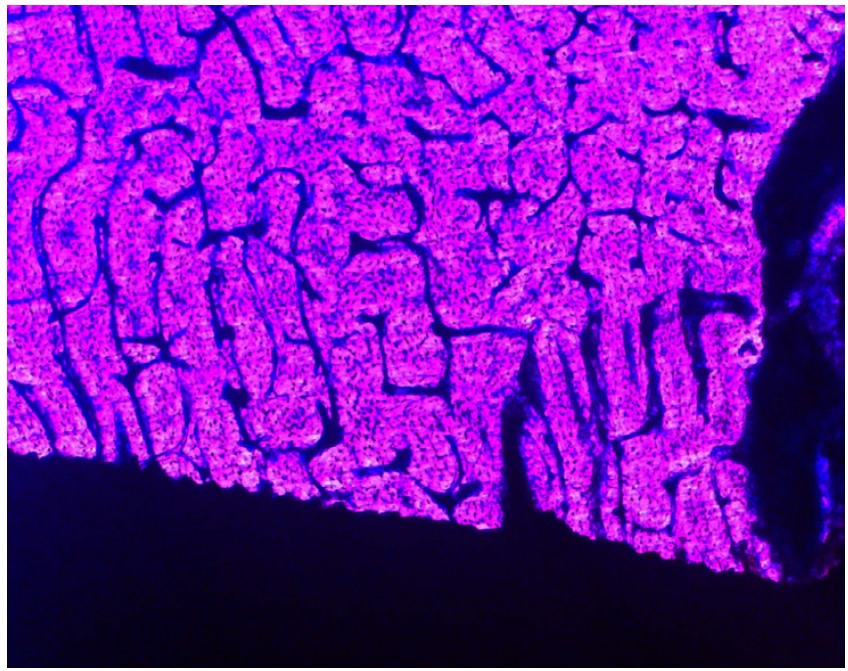

Figure 2

Finite element model of strain distribution in peri-implant bone. Bone strains do not exceed physiological values, bone dislocations are between 0 and $50 \mathrm{~nm}$.

sis: the calculation showed that physiological amplitudes of strain (500-3,000 $\mu$ strain) generated through mastication were homogenously distributed in peri-implant bone (Figure 1). The strain-energy density (SED) rate [4] under assessment of a $1 \mathrm{~Hz}$ loading cycle was $150 \mathrm{Jm}^{-3} \mathrm{~s}^{-1}$, peak dislocations were lower then $\mathrm{nm}$. Eigth male Göttinger minipigs, 14 to 16 months of age with an average body weight of $35 \mathrm{~kg}$, were used in this study. At day 3, day 7 and 28 animals were sacrificed with an overdose of T61 given intravenously.

Bone was in direct contact to the implant surface (bone/ implant contact rate $90 \%$ ) from day one of implant insertion, as quantified by undecalcified histological sections (Figure 2). This effect was substantiated by ultrastructural analysis of intimate osteoblast attachment (Figure 3) and mature collagen mineralisation at the titanium surface. We detected no loss in the intimate bone/implant bond during the experimental period of either control or experimental animals, indicating that immediate load had no adverse effect on bone structure in peri-implant bone (Figure 4).

Bone response on an implant surface depends on the reaction of cells and matrix towards the material surface as well as to the mechanical constraints in the vincinity of the implant. The maintenance of bone and its adaptation to external loads is based on a complex strain driven regulatory process of cells and matrix components $[5,6]$. Outside-in mechanical tension exert direct effects on cell 


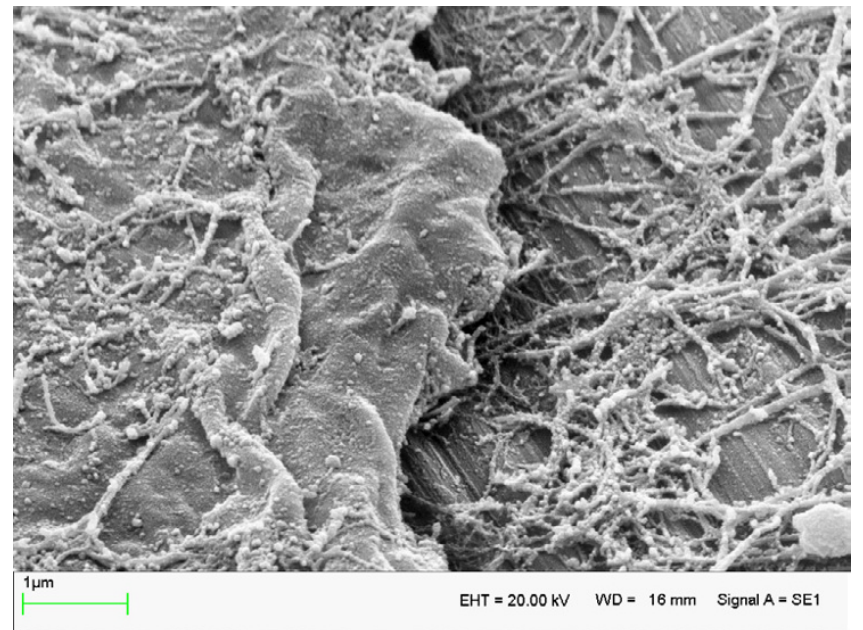

\section{Figure 3}

Histological picture of implant containing bone one day after insertion. Direct contact between bone and the implant is visible in the scanning electron micrographs.

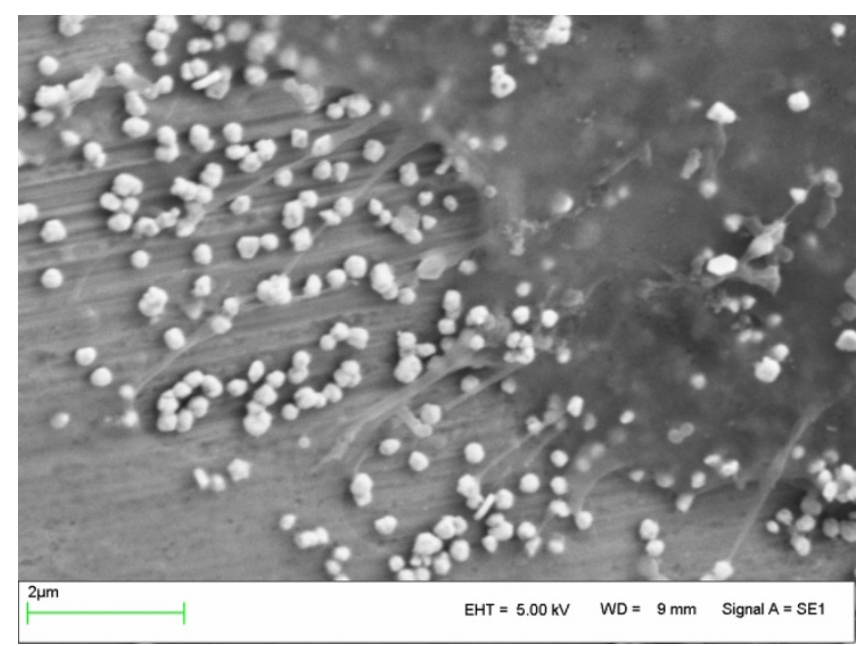

\section{Figure 4}

Immuno-scanning electron microscopy of intimate osteoblast adhesion at the titanium surface by fibronectin mediated focal adhesions (fractured specimens, one day under loading).

behaviour by activating biochemical signalling pathways and regulating gene expression through focal adhesions [7]. Frost [8] provided a paradigm for the mechanical control of cellular bone modelling, the process whereby bone is laid down onto surfaces without necessarily preceded by resorption. Recent investigations have indicated that the strain related bone modelling process is also regulative for bone tissue formation in healing tissue [9].

Using an atomic force microscope, a molecular mechanistic origin for the remarkably fast recovery of toughness after bone deformation was found, when deformation of less then $50 \mathrm{~nm}$ at the surface of multivalent ions (as in the case of Ti-oxide) is present [10]. Our understanding of osseointegration theorises that bone strengthening responds to a highly specific mechanical design. Even if long-term osseointegrated implants show what seems to be similar bone tissue reactions, osseointegration might be able to be achieved more rapidly than otherwise observed. Screw type titanium implants, as used in dental implantology, have in contrast to orthopaedic implants not only been convincingly shown very good clinical long-term success [11], but were also successful when load transfer is immediately present as seen in traumatology. In terms of clinical relevance, the load related bone reaction at the implant interface may in combination with substrate effects be responsible for an immediate osseointegration state.

\section{Competing interests}

The author(s) declare that they have no competing interests.

\section{Authors' contributions}

UJ designed the study, searched the database, extracted the data. AB helped with the study design and analysis. HPW had analysis the histological probes and UJ developed the implant design.

\section{References}

I. Crubezy E, Murail P, Girard L, Bernadou JP: False teeth of the Roman world. Nature 1998, 391:29.

2. Branemark PI, Adell R, Breine U, Hansson BO, Lindstrom J, Ohlsson A: Intra-osseous anchorage of dental prostheses. I. Experimental studies. Scand J Plast Reconstr Surg 1969, 3:8I-100.

3. Okumura A, Goto M, Goto T, Yoshinari M, Masuko S, Katsuki T, Tanaka T: Substrate affects the initial attachment and subsequent behavior of human osteoblastic cells (Saos-2). Biomaterials 200I, 22:2263-227I.

4. Turner $\mathrm{CH}$, Takano Y, Owan I: Aging changes mechanical loading thresholds for bone formation in rats. J Bone Miner Res 1995, 10:1544-1549.

5. Rubin CT, Pratt GW Jr, Porter AL, Lanyon LE, Poss R: Ultrasonic measurement of immobilization-induced osteopenia: an experimental study in sheep. Calcif Tissue Int 1988, 42:309-3I2.

6. Huiskes R, Ruimerman R, van Lenthe GH, Janssen JD: Effects of mechanical forces on maintenance and adaptation of form in trabecular bone. Nature 2000, 405:704-706.

7. Chicurel ME, Singer RH, Meyer CJ, Ingber DE: Integrin binding and mechanical tension induce movement of mRNA and ribosomes to focal adhesions. Nature 1998, 392:730-733.

8. Frost HM: The mechanostat: a proposed pathogenic mechanism of osteoporoses and the bone mass effects of mechanical and nonmechanical agents. Bone Miner 1987, 2:73-85.

9. Frost HM: A brief review for orthopaedic surgeons: Fatigue damage (microdamage in bone (its determinants and clinical implications). J Orthop Sci 1998, 3:272-28I. 
10. Thompson JB, Kindt JH, Drake B, Hansma HG, Morse DE, Hansma PK: Bone indentation recovery time correlates with bond reforming time. Nature 200I, 13:773-776.

II. Albrektsson T, Johansson : Osteoinduction, osteoconduction and osseointegration. C Eur Spine J 200I, 10:96-10I.

Publish with Biomed Central and every scientist can read your work free of charge

"BioMed Central will be the most significant development for disseminating the results of biomedical research in our lifetime. " Sir Paul Nurse, Cancer Research UK

Your research papers will be:

- available free of charge to the entire biomedical community

- peer reviewed and published immediately upon acceptance

- cited in PubMed and archived on PubMed Central

- yours - you keep the copyright

Submit your manuscript here:

http://www.biomedcentral.com/info/publishing_adv.asp 